\title{
Comparison of Efficacy of Insecticides and Biopesticides in Management of Rice Stem Borer Scirpophaga incertulas (Walker) and Leaf Folder (Cnaphalocrocis medinalis) in Kharif Rice under Farmers' Field Condition of Barak Valley of Assam
}

\author{
Nabadeep Saikia*, P. Chowdhury, Ejaful Ahmed, Abdur Rahman, Dinku Bora, \\ Sewali Saikia, Lakhan Sarkar, Bikash Nagaria and Swati Biswas
}

Krishi Vigyan Kendra, Arunachalm Cachar, Assam, India

*Corresponding author

\begin{abstract}
A B S T R A C T
Field trials were conducted during the kharif season of 2016 and 2017 in the farmers' field of Kalain and Borkhola development block of Cachar district of Assam for evaluation of efficacy of insecticides and biopesticides against rice stem borer and leaf folder in the field of High Yielding Variety (HYV) rice, Ranjit. The experiment comprised of 4 treatments including the farmers practice (FP). The study revealed that, lowest mean percentage of infestation of rice stem borer and leaf folder i.e. 3.52 and 2.58 per cent was recorded after 90 days of application with 85.27 and 89.73 per cent reduction over farmers practice in the plots treated with carbafuron 3G@30 kg/ha + 8 release of Trichogramma chelonis 50000/ha/week and Trichogramma japonicum @ $50000 /$ ha/week in the main field + spraying of neem based pesticide @ $5 \mathrm{ml} /$ litre between $4^{\text {th }}$ and $5^{\text {th }}$ release of T. chelonis and T. japonicum (T1), followed by 7.10 and 4.37 per cent with 70.29 and 80.31 per cent reduction over farmers practice when treated with Chloropyriphos $20 \mathrm{EC} @ 2 \mathrm{ml} /$ litre at vegetative and reproductive stage (T2) and 8.0 and 5.17 per cent infestation was recorded when treated with quinalphos $35 \mathrm{EC} @ 2.5 \mathrm{ml} /$ litre at vegetative and reproductive stage (T3) with 65.29 and 76.70 per cent reduction over farmers practice. In the farmers' practice highest mean infestation of 23.90 and 22.20 percent was recorded after 90 days of application of furadon 3G @ $7.5 \mathrm{~kg} / \mathrm{ha}$ (FP). Highest average yields of both the year $46.25 \mathrm{ql} / \mathrm{ha}$ was recorded in T1 with an increase of 27.44per cent over farmers' plot. In T2 average yield of $43.51 \mathrm{q} 1 / \mathrm{ha}$ was recorded with 19.90 per cent increase over FP, followed by $42.45 \mathrm{ql} / \mathrm{ha}$ in $\mathrm{T} 3$ with an increased percentage of 16.97 over FP. The lowest average yield of $36.29 \mathrm{ql} / \mathrm{ha}$ was recorded in FP. Similarly, highest B: C ratio of 1.58 (2016) and 1.579 (2017) was recorded in T1 followed by 1.47 (2016) and 1.51 (2017) in T2 and 1.43 (2016) and 1.47 (2017) was recorded with least B: C ratio of 1.30 (2016) and 1.34 (2017) was recorded in farmers plot (FP).
\end{abstract}

\begin{tabular}{|l|}
\hline K e y w o r d s \\
Rice stem borer, \\
$\begin{array}{l}\text { Scirpophaga } \\
\text { incertulas, Rice } \\
\text { leaf folder, } \\
\text { Chilonis, } \\
\text { Biopesticides, neem) }\end{array}$ \\
\hline Article Info \\
\hline $\begin{array}{l}\text { Accepted: } \\
\text { 26 May } 2020 \\
\text { Available Online: } \\
\text { 10 June } 2020\end{array}$ \\
\hline
\end{tabular}

\section{Introduction}

Rice is one among the three important food crops in the world. It serves as a staple diet for around 2.7 billion people. Asia is the major producer and consumer of rice in the world. In this continent, India is one of the world's largest producers of rice with an area of 43.7 million ha and annual production of 91.7 million tons accounting for $20 \%$ of all world rice production. Rice is India's preeminent crop, and is the staple food of the people of the eastern and southern parts of the country.

In Assam Kharif rice is grown in an area of 18.89 lakh hectares with a production of 37.27 lakh tones with a productivity of 20.03 
ql/ha. Cachar district which is situated in the southern part of Assam comprises of 91.14 thousand ha of kharif rice area with production and productivity of 1.95 lakh tones and $21.74 \mathrm{ql} / \mathrm{ha}$ respectively (Directorate of Economics and Statistics, Govt. of Assam).

There are over 70 pests infesting rice in India and 20 are of regular occurrence (Pathak, 1975). The pest causes $25-30 \%$ damage to rice crop (Lal, 1996). 20 of these are pests of major economic significance. The major pests of rice are brown plant hoppers, white backed plant hoppers, green leaf hoppers, yellow stem borers, pale headed striped borers, pink stem borers, rice leaf folders, rice case worms, rice hispas, rice bugs, rice grass hoppers etc.

The loss of yield of rice due to insect pests in India is estimated approximately upto 25 per cent (31 million tons) of hypothetical production (124.1 million tons) due to insect pests worth Rs 164300 million (Dhaliwal et al., 2004). Among the major pest attacking rice crop the stem borer, Scirpophaga incertulas (Walker) is the number one pest, which attack the crop both at vegetative and reproductive stages (Pasalu et.al., 2002). Rice stem borer (Scirpophaga incertulas.) and Leaf folder (Cnaphalocrosis medinalis) have been reported from all major rice growing areas and causes severe damage to the rice crop.

The leaf folder larvae cause injury to rice leaves by scrapping, folding and webbing them upto 60\%. (Prakash and Rao, 1999). Recently some botanical products like Trichocards \& neem products proved effective against some insect pest of rice, especially sucking pest (Saxena et al., 1986).

Changes in the physical environments, cultural practices, multiple cropping patterns, reduced genetic variability of high yielding rice varieties, application of high levels of nitrogenous fertilizer and a prophylactic use of pesticides are the major reasons of the RLF problem (Khan et al., 1989, Dale, 1994. Shepard et al., 1991 and De Kraker et al., 2000). A number of chemicals like Triazophos, Monocrotophos, Quinalphos, Chloropyriphos, Cartap hydrochloride, Fipronil or phorate $10 \mathrm{G}$ etc have been used indiscriminately against rice pests.

Management of RLF using synthetic chemicals has failed because of the pest resistance against them as well as the pest resurgence and environment pollution (Dale, 1994). The misuse and abuse during the last few decades caused wide spread damage to the environment and human health. In this circumstance, there is a growing need to promote eco-friendly biological control methods against insect pests of crops.

Trichogramma chilonis and Trichogramma japonicum is an effective egg-parasitoid of rice leaf folder and rice stem borers. After rearing it in the laboratory, its population can be augmented in the field to reduce the reliance on the chemicals for the control of lepidopteron pest insect of rice. Khan et al., 2005 , reported that the increase in paddy yield after augmentative releases of Trichogramma. chilonis, over control, ranged from 33 to 89.5 $\mathrm{kg} / \mathrm{acre}$.

In Barak valley, these pests multiply enormously, with a severe incidence observed during August-September till October. The overall leaf infestation by RLF and RSB was seen up to $35 \%$ which reduced the grain yield up to $40 \%$ in major rice growing tracts in Barak valley of Assam. Keeping in view, the present study was carried out to compare the efficacy of T. chilonis and Trichogramma japonicum to the efficacy of chloropyriphos $20 \mathrm{EC} @ 2 \mathrm{ml} / \mathrm{L}$ and quinalphos $30 \mathrm{EC} @ 2.5$ $\mathrm{ml} / \mathrm{L}$ of water for sustainable control of stem borer and leaf folder in rice. 


\section{Materials and Methods}

The experiment was conducted in the farmer's field of Kalain and Borkhola Development Block of Cachar district, Assam during 2016-17 and 2017-18 under Krishi Vigyan Kendra, Cachar, to evaluate the effectiveness of $T$. chilonis and T. japonicum for the management of rice stem borer and rice leaf folder.

The results were compared with the application of chloropyriphos@ $2 \mathrm{ml} / \mathrm{L}$ and quinalphos@ $2.5 \mathrm{ml} / \mathrm{L}$ in winter paddy var. Ranjit. Four different plots with an area of $666 \mathrm{~m} 2$ were used for four different treatments. The trial was replicated in the field of five farmers of Kalain Development Block and Borkhola Development block of Cachar district. The 25-30 days old seedlings were used for transplanting in main field.

Transplanting was done at $20 \times 15 \mathrm{~cm}$ spacing with recommended dose of fertilizer. Trichocards containing sterilized eggs of $T$. chilonis and T. japonicum were taken from the Assam Agricultural University, Jorhat, Assam for this trial. The cards were used in the paddy field before emergence of the adult parasite. T. chilonis and T. japonicum @ 50000/ha were released eight times at weekly interval starting from 30 days after transplanting of paddy.

The release of Trichogramma was coincided with the egg laying period of rice stem borers and leaf folders. Each Trichocard were cut into 6 pieces and evenly kept over the entire field by fixing them on bamboo sticks placed in required distance and covered with a disposable cup as protection against rain, wind, sunlight etc. in morning hours and just before emergence to avoid predation. A small cotton swab soaked in sucrose solution was pinned inside the cup as a food source of readily emerged parasite larvae.

\section{The treatments were}

T1: Eight releases of $T$. chilonis and $T$. japonicum @50000/ha/week starting from one month after transplanting with one spray of neem based insecticides @ $5 \mathrm{ml} / \mathrm{L}$ between third and fourth release of Trichogramma spp;

T2: Two sprays of Chloropyriphos 20 EC@ $2.0 \mathrm{ml} / \mathrm{L}$ one at vegetative and another at reproductive phase of the crop using a high volume knapsack sprayer using 500 liter of spray solution per hectare.

T3: Two sprays of Quinalphos 30 EC @ 2.5 $\mathrm{ml} / \mathrm{L}$ one at vegetative and another at reproductive phase of the crop using a high volume knapsack sprayer using 500 liter of spray solution per hectare.

T4: Farmers' Practice (FP), application of furadon 3G @ $7.5 \mathrm{~kg} / \mathrm{ha}$ at the incidence of pest.

Data were collected at 15 days interval after application of bio-pesticides till 90 days of first application, on the basis of dead heart or folded leaves by using following formula.

$$
\begin{aligned}
& \text { 1. Stem borer incidence }(\%) \\
& =\frac{\text { Number of dead hearts/white ears in the sample area }}{\text { Total number of tillers /paniclen the sample area }} \times 100 \\
& \text { 2. Folded leaves }(\%)=\frac{\text { No.of infested leaves in the sample area }}{\text { No. of total leaves sample area }} \times 100
\end{aligned}
$$

\section{Results and Discussion}

\section{Incidence of rice stem borer}

Table 1 shows the efficacy of egg releases of Trichogramma sp. Along with nursery treatment at 5 days before transplanting @30 $\mathrm{kg} / \mathrm{ha}$ and main field application of neem @ $3 \mathrm{ml} / 1 \mathrm{tr}$ between $3^{\text {rd }}$ and $4^{\text {th }}$ release of Trichogramma sp. (T1) was best in both the 
years, $2016(3.40 \%)$ and 2017 (3.65\%) where infestation of stem borer was recorded minimum among the treatments with average $85.27 \%$ reduction over farmers practice. Hassan (1994) used Trichogramma to control some 28 different caterpillar pest attacking different crops including rice. Mohanraj et al., (1995) used Tichogramma for the control of stem borers. Manjunath (1991) also found that inundative release of $T$. japonicum at 50000 per ha during egg laying period of rice stem borer reduced borer damage and increase crop yield. Application of chloropyriphos 20 EC @ 2ml/litre sprayed at vegetative stage and reproductive stage (T2) followed $\mathrm{T} 1$ in both the year with $6.8 \%$ and $7.4 \%$ respectively. Application of quinalphos 30 EC @ 2.5ml/litre sprayed at vegetative stage and reproductive stage (T3) closely followed T2 with $8.1 \%$ and $8.2 \%$ infestation in 2016 and 2017 respectively. These results are in accordance with Sontakke and Dash (2000) who reported chlorpyriphos, ethoprophos, carbofuran, fipronil at 50DAT afforded effective control of stem borer. Maximum infestation recorded in farmers' practice, where carbafuran 3G was applied @ $7.5 \mathrm{~kg} / \mathrm{ha}$ at the incidence of pest, with an infestation of $23.6 \%$ and $24.2 \%$. In T2 and T3 reduction of incidence over farmers plot recorded as average $70.29 \%$ and $66.53 \%$ respectively.

\section{Incidence of rice leaf folder}

Similar trend were recorded (Table 2) in control of leaf folder and use of releases of Trichogramma sp. along with nursery treatment at 5 days before transplanting @30 $\mathrm{kg} / \mathrm{ha}$ and main field application of neem @ $3 \mathrm{ml} / \mathrm{ltr}$ between $3^{\text {rd }}$ and $4^{\text {th }}$ release of Trichogramma sp. (T1) was best in both the years, $2016(2.25 \%)$ and $2017(2.3 \%)$ where infestation of leaf folder was recorded minimum among the treatments with average $89.73 \%$ reduction over farmers practice.
Our studies reveals that use of bio-pesticides has enhanced the effectiveness of Trichogramma chilonis. . The results are also in accordance with the results of Sagheer et al., 2008 who studied the integration of some biopesticides with Trichogramma chelonis for the sustainable management of rice leaf folder, Cnaphalocrocis medinalis (guenee). Application of chloropyriphos 20 EC @ $2 \mathrm{ml} /$ litre sprayed at vegetative stage and reproductive stage (T2) followed T1 in both the year with $4.30 \%$ and $4.44 \%$ respectively. Application of quinalphos 30 EC @ $2.5 \mathrm{ml} /$ litre sprayed at vegetative stage and reproductive stage (T3) closely followed T2 with $5.1 \%$ and $5.24 \%$ infestation in 2016 and 2017 respectively. In T2 and T3 reduction of incidence over farmers plot recorded as average $80.31 \%$ and $76.70 \%$ respectively in the respective years. Where, maximum infestation of $21.6 \%$ and $22.8 \%$ was recorded in the farmers' practice applied with carbafuron 3G@7.5 kg/ha at the time of incidence.

\section{Grain yield and economics}

The lowest yield of rice (Table 3) was recorded $(36.29 \mathrm{q} / \mathrm{ha})$ in the farmers' practice where insect pest management was done with use of insecticide furadon 3G @ $7.5 \mathrm{~kg} / \mathrm{ha}$ on occurrence of stem borer and leaf folder. Highest yield of $46.25 \mathrm{q} / \mathrm{ha}$ with an increase of $27.44 \%$ was recorded in treatment where $T$. chelonis and T. japonicum was released along with incorporation of Neem and nursery treatment with furadon 3G. Khan et al., 2005, reported that the increase in paddy yield after augmentative releases of Trichogramma. chilonis, over control, ranged from 33 to 89.5 $\mathrm{kg}$ /acre. Use of chloropyriphos 20 EC @2 $\mathrm{ml} / \mathrm{L}$ increased the yield of $19.90 \%$ over farmers' practice. Application of quinalphos 35 EC @ $2.5 \mathrm{ml} / \mathrm{L}$ recorded an increased in yield of $13.94 \%$ over farmers' practice with an average yield of $42.45 \mathrm{q} / \mathrm{ha}$. 
Table.1 Effect of insecticides on the incidence of stem borer,

Scirpophaga incertulas (Walker) in rice

\begin{tabular}{|c|c|c|c|c|c|c|}
\hline Treatment & $\begin{array}{c}\text { Days of } \\
\text { application }\end{array}$ & $\begin{array}{c}\text { Year \& } \\
\text { mean }\end{array}$ & $\begin{array}{l}T \text {. chilonis and } \\
T \text {. japonicum } \\
\text { (Incorporation with } \\
\text { Neem and nursery } \\
\text { management with } \\
\text { furadon } 3 G \text { ) }\end{array}$ & $\begin{array}{c}\text { Chloropyr } \\
\text { iphos } 20 \\
\text { EC }\end{array}$ & $\begin{array}{c}\text { Quinqlpho } \\
\text { s } 35 \text { EC }\end{array}$ & $\begin{array}{c}\text { Farmers } \\
\text { Practice } \\
\text { (FP) }\end{array}$ \\
\hline \multirow{18}{*}{ 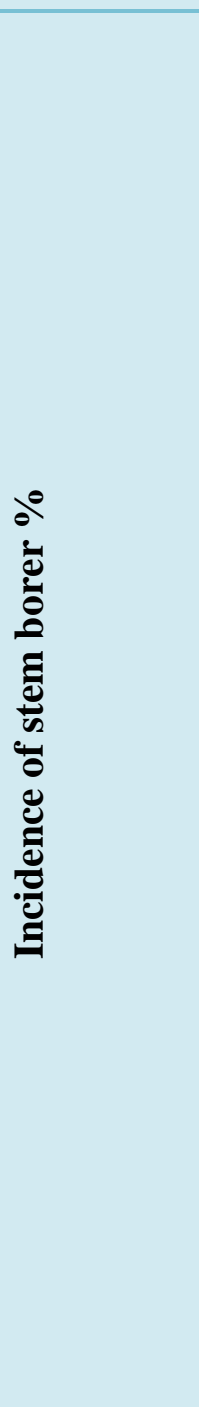 } & \multirow{3}{*}{$\begin{array}{l}15 \text { days of } \\
\text { application }\end{array}$} & 2016 & 0.00 & 1.00 & 2.00 & 5.6 \\
\hline & & 2017 & 0.03 & 1.20 & 2.10 & 5.8 \\
\hline & & Mean & 0.02 & 1.10 & 2.05 & 5.7 \\
\hline & \multirow{3}{*}{$\begin{array}{l}30 \text { days of } \\
\text { application }\end{array}$} & 2016 & 1.60 & 2.30 & 3.10 & 9.5 \\
\hline & & 2017 & 1.65 & 2.50 & 3.30 & 9.8 \\
\hline & & Mean & 1.63 & 2.40 & 3.20 & 9.65 \\
\hline & \multirow{3}{*}{$\begin{array}{l}45 \text { days of } \\
\text { application }\end{array}$} & 2016 & 2.20 & 3.50 & 4.50 & 13.4 \\
\hline & & 2017 & 2.15 & 4.00 & 4.70 & 13.8 \\
\hline & & Mean & 2.18 & 3.75 & 4.60 & 13.6 \\
\hline & \multirow{3}{*}{$\begin{array}{l}60 \text { days of } \\
\text { application }\end{array}$} & 2016 & 2.60 & 4.60 & 6.00 & 16.1 \\
\hline & & 2017 & 2.70 & 5.00 & 6.20 & 16.7 \\
\hline & & Mean & 2.65 & 4.80 & 6.10 & 16.4 \\
\hline & \multirow{3}{*}{$\begin{array}{l}75 \text { days of } \\
\text { application }\end{array}$} & 2016 & 3.12 & 6.00 & 7.20 & 19.4 \\
\hline & & 2017 & 3.45 & 6.00 & 7.50 & 20 \\
\hline & & Mean & 3.29 & 6.25 & 7.35 & 19.6 \\
\hline & \multirow{3}{*}{$\begin{array}{l}90 \text { days of } \\
\text { application }\end{array}$} & 2016 & 3.40 & 6.80 & 7.90 & 23.6 \\
\hline & & 2017 & 3.65 & 7.40 & 8.10 & 24.2 \\
\hline & & Mean & 3.52 & 7.10 & 8.00 & 23.9 \\
\hline 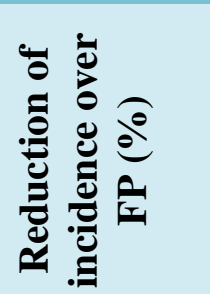 & & & 85.27 & 70.29 & 66.53 & - \\
\hline
\end{tabular}


Table.2 Effect of insecticides on the incidence of leaf folder Cnaphalocrocis medinalis Guenee

\begin{tabular}{|c|c|c|c|c|c|c|}
\hline Treatment & $\begin{array}{c}\text { Days of } \\
\text { applicati } \\
\text { on }\end{array}$ & $\begin{array}{c}\text { Year \& } \\
\text { mean }\end{array}$ & $\begin{array}{l}T . \text { chilonis and } \\
T . \text { japonicum } \\
\text { (Incorporation with } \\
\text { Neem and nursery } \\
\text { management with } \\
\text { furadon 3G) }\end{array}$ & $\begin{array}{c}\text { Chloropyr } \\
\text { iphos 20 } \\
\text { EC }\end{array}$ & $\begin{array}{c}\text { Quinqlpho } \\
\text { s 35 EC }\end{array}$ & $\begin{array}{c}\text { Farmers } \\
\text { Practice(FP) }\end{array}$ \\
\hline \multirow{18}{*}{ 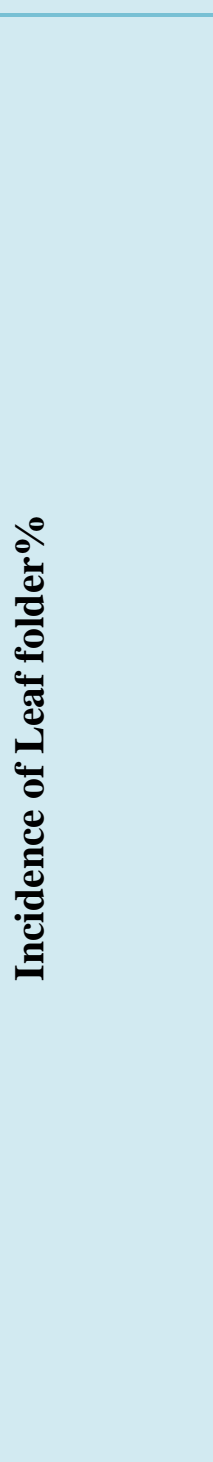 } & \multirow{3}{*}{$\begin{array}{c}15 \text { days of } \\
\text { applicatio } \\
n\end{array}$} & 2016 & 0.00 & 1.80 & 2.00 & 3.80 \\
\hline & & 2017 & 0.06 & 1.94 & 2.20 & 4.60 \\
\hline & & Mean & 0.03 & 1.87 & 2.10 & 4.20 \\
\hline & \multirow{3}{*}{$\begin{array}{l}30 \text { days } \\
\text { of } \\
\text { applicatio } \\
n\end{array}$} & 2016 & 0.79 & 2.80 & 3.10 & 7.24 \\
\hline & & 2017 & 1.00 & 2.92 & 3.20 & 7.88 \\
\hline & & Mean & 0.90 & 2.86 & 3.15 & 7.56 \\
\hline & \multirow{3}{*}{$\begin{array}{l}45 \text { days } \\
\text { of } \\
\text { applicatio } \\
\text { n }\end{array}$} & 2016 & 1.25 & 3.50 & 3.96 & 12.5 \\
\hline & & 2017 & 1.35 & 3.60 & 3.99 & 13.3 \\
\hline & & Mean & 1.30 & 3.55 & 3.98 & 12.9 \\
\hline & \multirow{3}{*}{$\begin{array}{l}60 \text { days } \\
\text { of } \\
\text { applicatio } \\
n\end{array}$} & 2016 & 1.70 & 3.80 & 4.40 & 15.3 \\
\hline & & 2017 & 1.86 & 3.96 & 4.70 & 15.4 \\
\hline & & Mean & 1.78 & 3.86 & 4.55 & 15.35 \\
\hline & \multirow{3}{*}{$\begin{array}{c}75 \text { days } \\
\text { of } \\
\text { applicatio } \\
n\end{array}$} & 2016 & 2.04 & 4.10 & 4.60 & 18.2 \\
\hline & & 2017 & 2.15 & 4.22 & 4.84 & 18.6 \\
\hline & & Mean & 2.10 & 4.16 & 4.72 & 18.4 \\
\hline & \multirow{3}{*}{$\begin{array}{l}90 \text { days } \\
\text { of } \\
\text { applicatio } \\
n\end{array}$} & 2016 & 2.25 & 4.30 & 5.10 & 21.5 \\
\hline & & 2017 & 2.30 & 4.44 & 5.24 & 22.8 \\
\hline & & Mean & 2.28 & 4.37 & 5.17 & 22.2 \\
\hline 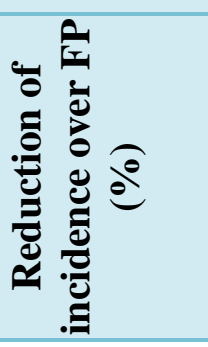 & & & 89.73 & 80.31 & 76.70 & - \\
\hline
\end{tabular}


Table.3 Grain yield

\begin{tabular}{|c|c|c|c|c|c|c|c|}
\hline Treatment & Dose & $\begin{array}{l}2016 \\
\text { Yield } \\
\text { q/ha } \\
\end{array}$ & $\begin{array}{l}\% \\
\text { increase } \\
\text { over FP }\end{array}$ & $\begin{array}{l}2017 \\
\text { Yield } \\
\text { q/ha }\end{array}$ & $\begin{array}{l}\% \\
\text { increase } \\
\text { over FP }\end{array}$ & $\begin{array}{l}\text { Mean } \\
\text { Yield } \\
\text { q/ha }\end{array}$ & $\begin{array}{l}\% \\
\text { over } \\
\text { FP }\end{array}$ \\
\hline $\begin{array}{l}\text { T.chilonis and T.japonicum (Incorporation with Neem } \\
\text { and nursery management with furadon } 3 G \text { ) }\end{array}$ & $\begin{array}{l}5 \text { cards/week, } \\
3 \mathrm{ml} / \mathrm{litre}, \\
30 \mathrm{~kg} / \mathrm{ha}\end{array}$ & 46.7 & 28.15 & 45.80 & 26.76 & 46.25 & 27.44 \\
\hline Chloropyriphos 20 EC & $2 \mathrm{ml} /$ litre & 43.88 & 20.42 & 43.15 & 19.40 & 43.51 & 19.90 \\
\hline Quinqlphos 35 EC & $2.5 \mathrm{ml} /$ litre & 42.80 & 17.5 & 42.10 & 16.52 & 42.45 & 16.97 \\
\hline FP (Furadon3G) & $5 \mathrm{~kg} / \mathrm{ha}$ & 36.44 & - & 36.13 & - & 36.29 & - \\
\hline
\end{tabular}

Table.4 Economics

\begin{tabular}{|c|c|c|c|c|c|c|c|c|c|c|c|}
\hline & \multicolumn{3}{|c|}{ Cost of cultivation } & \multicolumn{3}{|c|}{ Gross Return Rs./ha } & \multicolumn{3}{|c|}{ Net Return Rs./ha } & \multicolumn{2}{|c|}{ B:C Ratio } \\
\hline & 2016 & 2017 & Mean & 2016 & 2017 & Mean & 2016 & 2017 & Mean & 2016 & 2017 \\
\hline $\begin{array}{l}\text { T.chilonis and T.japonicum (Incorporation } \\
\text { with Neem and nursery management with } \\
\text { furadon } 3 G \text { ) }\end{array}$ & 38400 & 39525 & 38963 & 60710 & 64120 & 62415 & 22310 & 24595 & 23453 & 1.58 & 1.58 \\
\hline $\begin{array}{l}\text { Chloropyriphos } \\
20 \text { EC }\end{array}$ & 38738 & 39900 & 39319 & 57044 & 60410 & 58727 & 18306 & 20510 & 19408 & 1.47 & 1.51 \\
\hline Quinqlphos 35 EC & 38850 & 40088 & 39469 & 55640 & 58940 & 57290 & 16790 & 18852 & 17821 & 1.43 & 1.47 \\
\hline FP (Furadon3G) & 36375 & 37500 & 36938 & 47372 & 50582 & 48977 & 10997 & 13082 & 12040 & 1.30 & 1.34 \\
\hline
\end{tabular}


In the present study (Table 4) Gross return (Rs 60710/ha), net return (Rs 23453/ha) and B: C ratio (1.58) found highest where $T$. chelonis and T. japonicum was released along with incorporation of Neem and nursery treatment with furadon $3 \mathrm{G}$. It is obvious that the highest gross return and net return along with highest $B$ : $C$ ratio must be attributed to highest grain yield.

On the basis of reduction in incidence of rice stem borer and leaf folder and result of yield and Economics of rice cultivation under investigation, it is concluded that the release of $T$. chelonis and $T$. japonicum and incorporation of Neem and nursery treatment with furadon $3 \mathrm{G}$ proved to be the most effective in control of rice stem borer and leaf folder under prevailing micro farming situation.

\section{Acknowledgement}

Firstly, we are grateful to Dr. P. Pathak, Director of Extension Education and Dr. M. Neog, Associate Director of Extension Education, Assam Agricultural University, Jorhat for giving us the permission to conduct the valuable research work. We also thankful to Dr. P. Chowdhury, Sr. scientist \& Head, Krishi Vigyan Kendra, Cachar for his mentorship and guidance till completion of the work.

\section{References}

Dale, D. 1994. Insect Pests of rice plant, their biology and ecology. In: Heinrches, E.A. (Ed.), Biology and Management of Rice Insects. Wiley Eastern Ltd., New York. pp. 363-485.

De Kraker, R. Rabbinge, A. van Huis, J.C. van Lenteren and K.L. Heong. 2000. Impact of nitrogenous-fertilization on the population dynamics and natural control of rice leaf folders
(Lepidoptera: Pyralidae), Inter. Pest Manag. 46: 225-235.

Dhaliwal, G.S., Arora, R. and Dhawan, A.K. 2004. Indian J. Ecol. 31 (1): 1-7

Directorate of Economics and Statistics, Govt. of Assam (2016) District wise Area, Production and Yield of Different Crops

Hassan, S.A.1994. Strategies to select Trichogramma species for use in biological control. In: Biological control with egg parasitoids, (Eds.): E. Wajnberg and S.A. Hassan, pp. 55-71. Oxon, U.K., CAB International.

Khan, M.A. and S. Kumar. 2005. Bio-efficacy of Trichogramma spp. Against yellow stem borer and leaf folder in rice ecosystem. Ann. Plant Prot. Sci. 13(1):97-99.

Khan, Z.R., B.P. Rueda and P. Caballero. 1989. Behavioral and physiological responses of rice leaf folder, Cnaphalocrocis medinalis to selected wild rices, Entomol. Exp. Apli, 52:7- 13.

Lal, O.P. 1996. Recent Advances in Entomology, (Ed). Lal, O.P. APC Publications Pvt. Ltd. New Delhi, 392 PP.

Manjunath, T.M. 1991. Indo-USSR Joint Workshop on Problems and Potentials of Biocontrol of Pests and Diseases, June 26-28, 1990, Biological Control Centre, National Centre for Integrated Pest Management, Bangalore, India. pp. 31-56.

Mohanraj, P., K. Veenakumari and A.B. Mandal. 1995. Biocontrol of yellow stem borer using Trichogramma-a parasitoid native to Andamans. Rice Biotechnology, Quarterly, USA, 23: 9 10.

Pasalu, I.C. Krishnaiah, N.V., Katti, G. and Varma, N.R.G. (2002). IPM in rice. IPM Mitr. 45-55 pp

Pathak, M.D. (1975). Insect pest of Rice. International Rice Research Institute, Los Banos, Phillippines. pp 68. 
Prakash, A. and Rao, J. 1999. In. "Insect pests of cereal and their management" Applied Zoologist Research Association, CRRI, Cuttack, pp. I-168.

Sagheer M, Ashfaq M, Hasan M.U. and Rana S. A. 2008. Integration of some biopesticides and trichogramma chilonis for the sustainable management of rice leaf folder, cnaphalocrocis medinalis (guenee) (lepidoptera: pyralidae). Pak. J. Agri. Sci. 45(1):6974.

Saxena, R.C; Kareem, A.A.; Palanginan, E.L. and Malayba, M.T. 1986. Systemic foliar application of neem seed bitters to control of GLH and RTV diseases. Int. Rice Res. Newsl., 14 (1): 31

Shepard, B.M., Z.R. Khan, M.D. Pathak and E.A. Heinrichs. 1991. Management of insect pests of rice in Asia. In: D. Pimentel, Editor, Handbook of Pest Management in Agriculture (second ed.), CRC Press, pp. 225-278.

Sontakke, B.K. and Dash, A.N. Field efficacy of some granular insecticides against pests of rice. Indian J.Ent., 62(4):353$357(2000)$.

\section{How to cite this article:}

Nabadeep Saikia, P. Chowdhury, Ejaful Ahmed, Abdur Rahman, Dinku Bora, Sewali Saikia, Lakhan Sarkar, Bikash Nagaria and Swati Biswas. 2020. Comparison of Efficacy of Insecticides and Biopesticides in Management of Rice Stem Borer Scirpophaga incertulas (Walker) and Leaf Folder (Cnaphalocrocis medinalis) in Kharif Rice under Farmers' Field Condition of Barak Valley of Assam. Int.J.Curr.Microbiol.App.Sci. 9(06): 3462-3470. doi: https://doi.org/10.20546/ijcmas.2020.906.408 